American Journal of Applied Sciences 6 (11): 1892-1896, 2009

ISSN 1546-9239

(C) 2009 Science Publications

\title{
Effect of Enhancing Urea-Humic Acid Mixture with Refined Acid Sulphate Soil
}

\author{
${ }^{1}$ Mohd Taufik Mohd Yusuff, ${ }^{1}$ Osumanu Haruna Ahmed and ${ }^{2}$ Nik Muhamad Ab. Majid \\ ${ }^{1}$ Department of Crop Science, Faculty of Agriculture and Food Sciences, University Putra Malaysia, \\ Bintulu Campus, Sarawak, 97008 Bintulu, Sarawak, Malaysia \\ ${ }^{2}$ Department of Forest Management, Faculty of Forestry, University Putra Malaysia, 34300 UPM \\ Serdang, Selangor, Malaysia
}

\begin{abstract}
Problem statement: Acid Sulphate Soil (ASS) is a problem soil partly because of its high acidity. This low $\mathrm{pH}$ could be exploited to reduce ammonia loss from urea by reducing soil microsite $\mathrm{pH}$. The use Humic Acid (HA) to control ammonia loss from urea has been reported but the cost of this material is high. This laboratory study compared the effect of enhancing urea-humic acid mixtures with acid sulphate soil on $\mathrm{NH}_{3}$ loss, $\mathrm{pH}$, exchangeable ammonium and available nitrate contents. Approach: Humic acid, acid sulfate soil and soil used in the incubation study were analyzed for selected soil physical-chemical properties using standard procedures. Urea-HA-ASS mixtures were prepared and ammonia volatilization of the mixtures was evaluated by the closed-dynamic air flow system. The treatments were evaluated in a randomized complete block design with 3 replications. Standard procedures were used to determine ammonia loss, soil $\mathrm{pH}$, exchangeable ammonium and available nitrate at 22 days of incubation. Data obtained were analyzed using analysis of variance and Duncan's test using Statistical Analysis System (SAS) version 9.2. Results: Urea amended with $0.75 \mathrm{~g}$ ASS significantly reduced ammonia volatilization. Although the use of appropriate amount of acid sulphate soil to control ammonia loss is possible, excessive use of this material is not recommended because of $\mathrm{Fe}$ in it. Conclusion: Urea amended with $0.75 \mathrm{~g}$ ASS reduced ammonia.
\end{abstract}

Key words: acid sulphate soil, urea, humic acid, ammonia loss

\section{INTRODUCTION}

Acid Sulphate Soils (ASS) are extensive in this region $^{[1,2]}$ A recent study on ammonia loss from urea by using acidic materials such as Humic Acid (HA) has been successful ${ }^{[3,4]}$. Besides reducing ammonia loss, the mixture of urea-HA improves plant growth and development ${ }^{[5]}$. However, large scale production of HA in Malaysia is still limited as this country imports HA based fertilizers from China and Australia at a high $\operatorname{cost}^{[2]}$.

Considering the low $\mathrm{pH}$ and low cost of ASS, the use of ASS may help to reduce the amount of HA in urea-HA mixture. Besides, this approach may help to increase $\mathrm{N}$ use efficiency in agriculture. Appropriate amount of HA may also help to chelate heavy metals such as $\mathrm{Al}, \mathrm{Fe}$ and so on. The objective of this study was to investigate the effects of enhancing urea-HA with ASS on ammonia loss, exchangeable ammonium $\left(\mathrm{NH}_{4}\right)$ and available nitrate $\left(\mathrm{NO}_{3}\right)$ under laboratory condition.

\section{MATERIALS AND METHODS}

The ASS was collected from Kuching, Sarawak (Telaga Air mangrove and Rempagi) at $0-15 \mathrm{~cm}$ depth. The soil was air dried, meshed and sieved to pass a 2 $\mathrm{mm}$ sieve before it was characterized for selected soil chemical properties such as $\mathrm{pH}$ using glass electrode $^{[6]}$, Cation Exchange Capacity (CEC) by leaching using $1 \mathrm{~N}$ ammonium acetate (adjusted to $\mathrm{pH}$ 7) followed by steam distillation technique ${ }^{[7]}$, exchangeable cations ( $\mathrm{K}, \mathrm{Ca}, \mathrm{Mg}, \mathrm{Na}$ and $\mathrm{Fe}$ ) by the double acid method and atomic absorption spectrophotometry (A Analyst 800, Perkin Elmer Instruments, Norwalk, CT) ${ }^{[8]}$.

The HA was isolated from a tropical peat (hemist) soil at $0-25 \mathrm{~cm}$ depth using the method described by Susilawati et al. ${ }^{[9,10]}$. The oven dried yield of HA was expressed as percentage of the weight of soil used. Functional group analysis of the HA was conducted by the method described by Inbar et al. ${ }^{[11]}$. The level of humification of $\mathrm{HA}$ was determined by $\mathrm{E}_{4} / \mathrm{E}_{6}$ method

Corresponding Author: Mohd Taufik Mohd Yusuff, Department of Crop Science, Faculty of Agriculture and Food Sciences, University Putra Malaysia, Bintulu Campus, Sarawak, 97008 Bintulu, Sarawak, Malaysia 
Am. J. Applied Sci., 6 (11): 1892-1896, 2009

using spectroscopy ${ }^{[12]}$. The model of the spectrometer used was Lambda 25 UV/VIS (Shelton, CT, USA). Both dry HA and ASS was meshed again to pass sieve less than $1 \mathrm{~mm}$ after which they were used to mix urea $^{[3]}$.

Urea, HA and ASS mixture was prepared using the method described by Ahmed et al. ${ }^{[3]}$ with some modification where the materials were weighed separately based on the treatments below before mixing them in plastic vials by using reciprocal mechanical shaker (200 rpm for $10 \mathrm{~min})$.

The incubation study was conducted in a closed-dynamic air flow system ${ }^{[3]}$ in a Complete Randomized Design (CRD) with three replications for 22 days. The treatments evaluated were:

- $\quad$ Soil alone (T1)

- $2.02 \mathrm{~g}$ urea alone (T2)

- $2.02 \mathrm{~g}$ urea+0.50 g HA+0.50 g ASS (T3)

- $2.02 \mathrm{~g}$ urea+0.75 g HA+0.75 g ASS (T4)

- $2.02 \mathrm{~g}$ urea+1.00 g HA+1.00 g ASS (T5)

- 2.02 g urea+0.50 g HA (T6)

- $2.02 \mathrm{~g}$ urea+0.75 g HA (T7)

- $2.02 \mathrm{~g}$ urea+1.00 g HA (T8)

A total amount of $250 \mathrm{~g}$ Nyalau series (Typic Paleudults), sandy clay loam in texture (Sampled at UPM Bintulu Sarawak campus) was used in the incubation study to evaluate treatments. The soil was analyzed for field capacity ${ }^{[8]}$, bulk density ${ }^{[8]}, \mathrm{CEC}^{[7]}$, exchangeable cation $(\mathrm{K}, \mathrm{Ca}, \mathrm{Mg}, \mathrm{Na} \text { and } \mathrm{Fe})^{[8]}$, total $\mathrm{N}^{[13]}$, inorganic $\mathrm{N}\left(\mathrm{NO}_{3} \text { and } \mathrm{NH}_{4}\right)^{[7]}$ and $\mathrm{pH}^{[6]}$ before and after the incubation study.

Analysis of variance was used to test treatment effects and means were compared using Duncan's test $^{[14]}$. The Statistical Analysis System (SAS) version 9.2 was used for this analysis.

\section{RESULTS}

The selected chemical properties of the soil (Table 1) were typical of Nyalau series and were consistent with those reported by Paramananthan ${ }^{[15]} \cdot \mathrm{pH}$ and CEC of the ASS were similar to those reported by Shamsuddin ${ }^{[2]}$ who also give the properties of tropical ASS. The carbon, phenolic, carboxylic and total acidity of HA were comparable with those reported by Schnitzer ${ }^{[16]}$ and $\operatorname{Tan}^{[17]}$.

The daily loss of $\mathrm{NH}_{3}$ is shown in Fig. 1. The treatments with urea additives temporary delayed $\mathrm{NH}_{3}$ loss (Fig. 1) compared to urea alone (T2). Except for T3 and T6, total ammonia loss over 22 days of incubation for the treatments with urea additives was significantly lower (Table 2) than that of urea alone (T2).
Table 1: Selected chemical and physical characteristics of HA, ASS and Nyalau series

\begin{tabular}{|c|c|c|c|}
\hline Property & ASS & HA & Soil \\
\hline $\mathrm{pH}$ (water) & 3.45 & nd & 4.85 \\
\hline $\mathrm{pH}(1 \mathrm{M} \mathrm{KCl})$ & nd & nd & 3.65 \\
\hline Total organic carbon $(\%)$ & nd & 55.59 & nd \\
\hline $\mathrm{CEC}\left(\mathrm{cmol} \mathrm{kg}^{-1}\right)$ & 40.50 & a & 21.25 \\
\hline Carboxylic group $\left(\mathrm{cmol} \mathrm{kg}^{-1}\right)$ & nd & 300 & nd \\
\hline Phenolic group $\left(\mathrm{cmol} \mathrm{kg}^{-1}\right)$ & nd & 220 & nd \\
\hline Total acidity ${ }^{\mathrm{a}}\left(\mathrm{cmol} \mathrm{kg}^{-1}\right)$ & nd & 520 & nd \\
\hline Total N & nd & nd & 0.4132 \\
\hline Exchangeable $\mathrm{K}\left(\mathrm{cmol} \mathrm{kg}^{-1}\right)$ & 0.0827 & nd & 0.8016 \\
\hline Exchangeable $\mathrm{Mg}\left(\mathrm{cmol} \mathrm{kg}^{-1}\right)$ & 0.2042 & nd & 0.0177 \\
\hline Exchangeable $\mathrm{Ca}\left(\mathrm{cmol} \mathrm{kg}^{-1}\right)$ & 0.0534 & nd & 0.0001 \\
\hline Exchangeable $\mathrm{Na}\left(\mathrm{cmol} \mathrm{kg}^{-1}\right)$ & 0.9163 & nd & 0.0280 \\
\hline Exchangeable $\mathrm{NH}_{4}{ }^{+}$ & nd & nd & 0.1540 \\
\hline Available $\mathrm{NO}_{3}^{-}$ & nd & nd & 0.1243 \\
\hline Field capacity (\%) & nd & nd & 75.57 \\
\hline Texture & nd & nd & SCL \\
\hline
\end{tabular}

HA: Humic Acid; ASS: Acid Sulphate Soil; CEC: Cation Exchange Capacity; SCL: Sandy Clay Loam; nd: not determined; ${ }^{\text {a: }}$ CEC of humic acid $=$ total acidity

At the end of the study, T3-T8 had similar effect on soil $\mathrm{pH}$ even though those for T4, T6 and T7 were significantly higher than that of urea alone (T2). There was no significant effect of T2-T7 and T8 on available nitrate. In terms of exchangeable $\mathrm{NH}_{4}$, those of T4 and T7 were significantly lower than those of T2-T4 and T8.

The selected exchangeable cations presented in Table 3 show that all the treatments had no significant effect on the concentrations of $\mathrm{Ca}$ and $\mathrm{Mg}$. Only $\mathrm{K}$ under T4 was significantly higher than that of urea alone (T2). The concentrations of $\mathrm{K}$ for the other mixtures were not significantly different from that of urea alone except T7. The Na contents for all of the mixtures were significantly higher than that of urea alone (T2). Except for $\mathrm{T} 3$, the concentration of $\mathrm{Cu}$ under T4, to T8 were lower compared with urea alone (T2) while for Fe, only that for T5 statistically similar to the concentration of Fe for urea alone (T2). Being the two (T4 and T7) treatments which controlled ammonia loss better, the low exchangeable ammonium under T4 and $\mathrm{T} 7$ compared to $\mathrm{T} 2, \mathrm{~T} 5, \mathrm{~T} 6$ and $\mathrm{T} 8$ suggests temporary improvement in the retention of ammonium under the two treatments.

\section{DISCUSSION}

The reduction of total $\mathrm{NH}_{3}$ loss for T4, T5, T7 and T8 compared with urea alone (T2) was because of the temporary acidic condition at the urea microsite during urea hydrolysis. This observation was consistent with the research of Ahmed et al. ${ }^{[3,18]}$ who also found a 
Am. J. Applied Sci., 6 (11): 1892-1896, 2009

Table 2: Total amount of ammonia loss, soil $\mathrm{pH}$, available $\mathrm{NO}_{3}$ and exchangeable $\mathrm{NH}_{4}$ over 22 days of incubation

\begin{tabular}{llllc}
\hline Treatment & $\mathrm{NH}_{3}$ loss & $\mathrm{pH}$ water & Available $\mathrm{NO}_{3}\left(\mathrm{mg} \mathrm{kg}^{-1}\right)$ & Exchangeable $\mathrm{NH}_{4}\left(\mathrm{mg} \mathrm{kg}^{-1}\right)$ \\
\hline T1 & $0.00^{\mathrm{e}}$ & $4.57^{\mathrm{c}}$ & $14.02^{\mathrm{a}}$ & $28.00^{\mathrm{d}}$ \\
T2 & $49.80^{\mathrm{a}}$ & $7.23^{\mathrm{b}}$ & $21.02^{\mathrm{a}}$ & $994.70^{\mathrm{ab}}$ \\
T3 & $48.20^{\mathrm{ab}}$ & $7.33^{\mathrm{ab}}$ & $10.51^{\mathrm{a}}$ & $224.20^{\mathrm{d}}$ \\
T4 & $33.24^{\mathrm{d}}$ & $7.67^{\mathrm{a}}$ & $24.52^{\mathrm{a}}$ & $693.50^{\mathrm{c}}$ \\
T5 & $43.46^{\mathrm{b}}$ & $7.31^{\mathrm{ab}}$ & $21.02^{\mathrm{a}}$ & $963.20^{\mathrm{ab}}$ \\
T6 & $45.29^{\mathrm{ab}}$ & $7.62^{\mathrm{a}}$ & $14.01^{\mathrm{a}}$ & $837.10^{\mathrm{bc}}$ \\
T7 & $31.36^{\mathrm{d}}$ & $7.67^{\mathrm{a}}$ & $21.02^{\mathrm{a}}$ & $697.00^{\mathrm{c}}$ \\
T8 & $36.72^{\mathrm{c}}$ & $7.39^{\mathrm{ab}}$ & $14.01^{\mathrm{a}}$ & $1099.80^{\mathrm{a}}$ \\
\hline
\end{tabular}

Note: Different alphabets indicate significant difference between means using Duncan's test at $p=0.05$

Table 3: Selected exchangeable cations of Nyalau series over 22 days of incubation

\begin{tabular}{|c|c|c|c|c|c|c|}
\hline \multirow[b]{2}{*}{ Treatment } & \multicolumn{6}{|c|}{ Exchangeable $\left(\mathrm{mg} \mathrm{kg}^{-1}\right)$} \\
\hline & $\mathrm{K}$ & $\mathrm{Ca}$ & $\mathrm{Na}$ & $\mathrm{Mg}$ & $\mathrm{Cu}$ & $\mathrm{Fe}$ \\
\hline$\overline{\mathrm{T} 1}$ & $79.20^{\mathrm{a}}$ & $95.40^{\mathrm{a}}$ & $52.00^{\text {cd }}$ & $116.80^{\mathrm{a}}$ & $10.70^{\mathrm{a}}$ & $34.10^{\mathrm{ab}}$ \\
\hline $\mathrm{T} 2$ & $62.20^{\mathrm{c}}$ & $78.50^{\mathrm{a}}$ & $44.80^{\mathrm{d}}$ & $107.00^{\mathrm{a}}$ & $9.30^{\mathrm{a}}$ & $46.40^{\mathrm{a}}$ \\
\hline $\mathrm{T} 3$ & $60.90^{\mathrm{c}}$ & $115.20^{\mathrm{a}}$ & $69.80^{\mathrm{b}}$ & $127.30^{\mathrm{a}}$ & $9.50^{\mathrm{a}}$ & $11.40^{\mathrm{bc}}$ \\
\hline $\mathrm{T} 4$ & $70.70^{\mathrm{b}}$ & $104.50^{\mathrm{a}}$ & $85.80^{\mathrm{a}}$ & $131.30^{\mathrm{a}}$ & $7.00^{\mathrm{b}}$ & $0.00^{\text {cd }}$ \\
\hline T5 & $60.70^{\mathrm{c}}$ & $92.90^{\mathrm{a}}$ & $88.90^{\mathrm{a}}$ & $125.60^{\mathrm{a}}$ & $5.90^{\mathrm{b}}$ & $40.30^{\mathrm{a}}$ \\
\hline T6 & $62.00^{\mathrm{c}}$ & $79.20^{\mathrm{a}}$ & $53.60^{\mathrm{c}}$ & $105.10^{\mathrm{a}}$ & $4.00^{\mathrm{c}}$ & $9.60^{\mathrm{bc}}$ \\
\hline $\mathrm{T} 7$ & $54.90^{\mathrm{d}}$ & $94.50^{\mathrm{a}}$ & $66.20^{\mathrm{b}}$ & $111.10^{\mathrm{a}}$ & $3.60^{\mathrm{c}}$ & $0.00^{\mathrm{cd}}$ \\
\hline $\mathrm{T} 8$ & $62.10^{\mathrm{c}}$ & $119.00^{\mathrm{a}}$ & $84.20^{\mathrm{a}}$ & $123.20^{\mathrm{a}}$ & $3.90^{\mathrm{c}}$ & $0.80^{\text {cd }}$ \\
\hline
\end{tabular}

Note: Different alphabets indicate significant difference between means using Duncan's test at $\mathrm{p}=0.05$

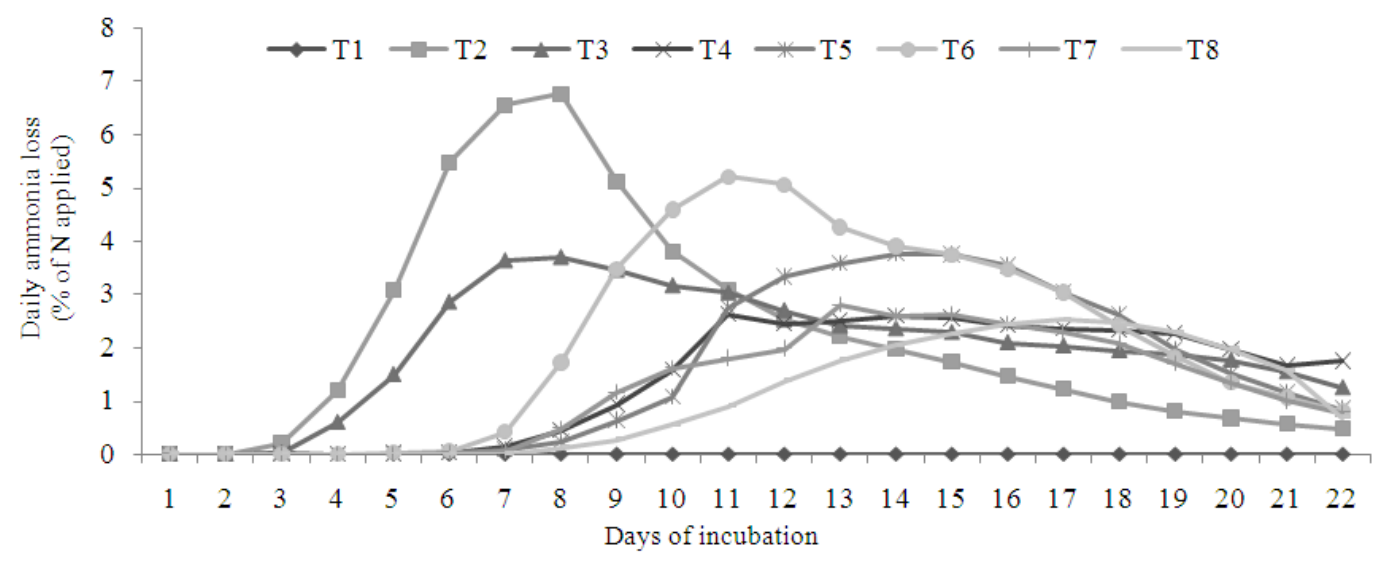

Fig. 1: Daily loss of ammonia from incubation. For key to treatments see materials and method

reduction in $\mathrm{NH}_{3}$ loss when urea was mixed with HA or TSP. This may have effectively increased the volume of soil with which urea was mixed with and also increased the time required for complete hydrolysis ${ }^{[4]}$. But for T3 and T6, the use of ASS and HA had similar effect as compared to T2 because the amounts of HA and ASS used were probably not sufficient to reduce $\mathrm{NH}_{3}$ loss.

Lack of significant difference in available nitrate regardless of treatment suggests favorable formation of exchangeable ammonium over nitrate as the concentrations of ammonium were generally high for all the treatments except for T3. The low exchangeable ammonium for $\mathrm{T} 3$ could be due to high ammonia loss (Table 2).
The significant increase in soil $\mathrm{pH}$ for $\mathrm{T} 2$, to $\mathrm{T} 8$ treatments suggests the occurrence of urea hydrolysis and this could be partly because of consumption of more hydrogen ions. The sharp increase in soil $\mathrm{pH}$ could also be due to the soil texture (Table 1).

The mixtures did not generally have significant effect on $\mathrm{K}, \mathrm{Ca}$ and $\mathrm{Mg}$ contents because they were free from these cations unlike $\mathrm{Na}$ which may have come from HA. This was because $\mathrm{NaOH}$ hydroxide was used for the isolation of the HA from peat. The presence of $\mathrm{Na}$ suggests that the HA used in this study was not hundred percent pure. This is understood because even highly purified HA may contain some amount of mineral matter. The lower contents of $\mathrm{Cu}$ and $\mathrm{Fe}$ of 
urea additives compared with urea alone could be attributed to chelation because the HA of the mixtures has the ability to chelate $\mathrm{Cu}, \mathrm{Fe}$ and $\mathrm{Al}$ in particular. The fact that chelation was profound for Fe suggests that the Fe of ASS can be controlled by the presence $\mathrm{HA}$ in the treatments.

\section{CONCLUSION}

Mixing urea with $0.75 \mathrm{~g}$ ASS (T4) effectively reduces ammonia loss.

\section{ACKNOWLEDGEMENT}

The researchers acknowledge the financial support (Research University Grant Scheme) received from the Ministry of Higher Education, Malaysia via University Putra Malaysia.

\section{REFERENCES}

1. Dent, D., 1986. Acid Sulphate Soil: A Base Line for Research and Development. ILRI Publication, Wageningen, The Netherlands, ISBN: 9070260980 .

2. Shamsuddin, J., 2006. Acid Sulfate Soils in Malaysia. University Putra Malaysia Press Serdang, Selangor, ISBN: 9832871875, pp: 137.

3. Ahmed, O.H., H. Aminuddin and M.H.A. Husni, 2006. Ammonia volatilization and ammonium accumulation from urea mixed with zeolite and triple superphosphate. Acta Agric. Scandinavica, Plant Soil Sci., 58: 182-186. DOI: 10.1080/09064710701478271.

4. Susilawati, K., O.H. Ahmed, A.M. Nik Muhamad, M.Y. Khanif and M.B. Jalloh., 2009. Effect of organic based $\mathrm{n}$ fertilizers on dry matter (Zea mays L.), Ammonium and nitrate recovery in acid soil of Sarawak Malaysia. Am. J. Applied Sci., 6: $1282-1287$.

5. Y. Fahri and D. Murat, 2008. Effect of humic acid applications on the root-rot diseases caused by Fusarium spp. on tomato plants. Plant Pathol. J., 7(2): $179-182 . \quad$ ISSN 1812-5387 DOI: 10.3923/ppj.2008.179.182.

6. Brady, N.C. and Weil, R.R. 2002. The Nature and Properties of Soils. 13th Edn., Pearson Education, Inc., New Jersey, ISBN: 0130167630, pp: 498-540.

7. Keeney, D.R. and D.W. Nelson, 1982. NitrogenInorganic Forms. In: Methods of Soil Analysis, Part 2, Page, A.L., Page, A.L., D.R. Keeney, D.E. Baker and R.H. Miller et al. (Eds.), 2nd Edn., Agron. Monogr. 9, ASA and SSSA, Madison, WI., ISBN: 0891180729.
8. Tan, K.H., 1996. Soil Sampling, Preparation and Analysis. Marcel Dekker, Inc., New York, ISBN: 0824796756, pp: 408.

9. Susilawati, K., O.H. Ahmed, A.M. Nik Muhamad and M.Y. Khanif, 2008. Simple method purifying humic acids isolated from tropical hemists (peat soil). Am. J. Applied Sci., 5: 1812-1815.

10. Ahmed, O.H., M.H.A. Husni, A.R. Anuar and M.M. Hanafi, 2005. Determination of minimal duration necessary for the isolation of humic acid contained in composted pineapple leaves. Fruits 60: 115-120. DOI: 10.1051/fruits:2005022

11. Inbar, Y., Y. Chen and Y. Harder, 1990. .Humic substance formed during the composting of organic matter. Soil Sci. Soc. Am. J., 54: 1316-1323. http://soil.scijournals.org/cgi/content/abstract/54/5/ 1316.

12. Stevenson, F.H., 1994. Humus Chemistry: Genesis, Composition, Reactions. John Wiley and Son, New York, ISBN: 0471594741, pp: 378-486. http://www.scipub.org/fulltext/ajas/ajas5121812-18 15.pdf

13. Jones, J.B., 2001. Laboratory Guide for Conducting Soil Tests and Plant Analysis. CRC Press, USA., ISBN: 0849302064, pp: 209-212.

14. SAS., 2001. SAS/STAT Software. SAS Institute, Cary, NC., ISBN: 10: 1580258506.

15. Paramananthan, S., 2000. Soils of Malaysia: Their Characteristics and Identification. Academy of Sciences Malaysia, Kuala Lumpur, ISBN: 9839445065.

16. Schnitzer, M. and C.M. Preston, 1986. Analysis of humic acids by solution and solid state carbon-13 nuclear magnetic resonance. Soil Sci. Soc. Am. J., 50: 326-331.http://soil.scijournals.org

17. Tan, K.H., 2003. Humic Matter in Soil and the Environment: Principles and Controversies. Marcel Dekker, Inc., New York, ISBN: 0-8247-4272-9, pp: 34-71.

18. Siva, K.B., H. Aminuddin, M.H.A. Husni and A.R. Manas, 1999. Ammonia volatilization from urea as affected by tropical-based palm oil palm effluent (pome) and peat. Communications. Soil Sci. Plant Anal., 30: 785-804. DOI: 10.1080/00103629909370246

19. Tan, K.H., 2000. Environmental Soil Science Second Edition Revised and Expanded. Marcel Dekker, Inc., United States, ISBN: 0824703405, pp: 252. 
20. Havlin, J.L., J.D. Beaton, S.M. Tisdale and W.L. Nelson, 1999. Nitrogen. In: Soil Fertility and Fertilizers: An Introduction to Nutrient Management. 6th Edn., Prentice Hall, Inc., Upper Saddle River, New Jersey, USA., ISBN: 0136268064, pp: 86-153.
21. Leung, W.H. and A. Kimaro, 1997. Soil amendment with humic acid and phosphate to promote sarption and retard mobility of zinc. Virgina J. Sci., 48: 252-258. 